らべた。之等の添加物は培地の $\mathrm{pH}$ 总低下させて倠 菌の発育を阻止するからである。吾々の少数経験では uniform medium に対して菌㥀線的な response を示したが、沵加境地では若干のdrift の增大が文ら れた。てれらの点仙今後もつと明瞭にしたい之考えて いる。

\section{上顎右側中切摇の唇側近心に副根有する 稀有なる一例}

第一绍部一忙

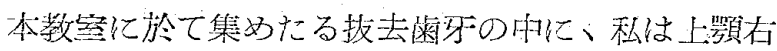
側中切歯の䨑根唇側部近心に一副根を持つた例荧発見

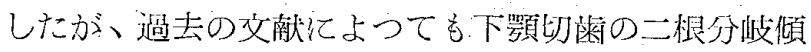

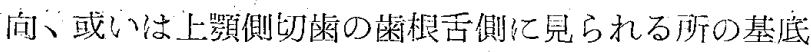
結節に相恥したる附加的なる割根は往々にして出現す

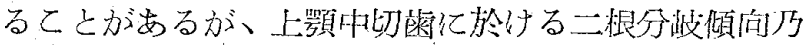

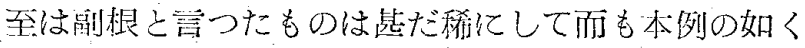

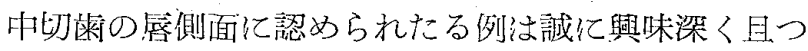
珍しい例で名つた。即ち此の蒾牙の外形は一船の中断

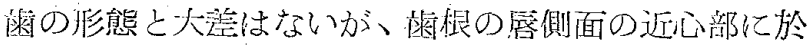
て小さな乫起状の副根か㲔められた。之は先づ近心側

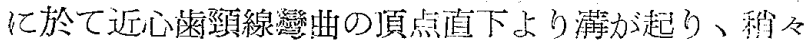

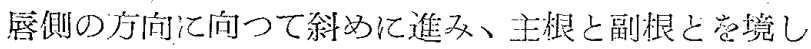
て次第に淟は深くなりやかて完全に分波していた。东

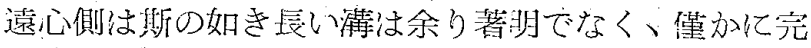
全分波する直前より分波の傾问壱示し始めていた。此

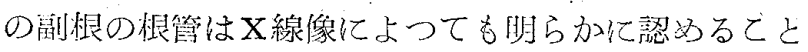
は㧮来な加つた。

\section{質問 理工 林}

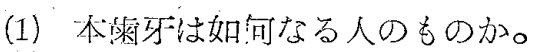

(2) 復占的なものではないと云うが、他の哺乳類も 夫ふ進化しているからその原始的㭙期には二根切 蒾があつたかを知えないので注ないか。

\section{解答 演者}

(1) 拔去实可觉集多たので不明である。

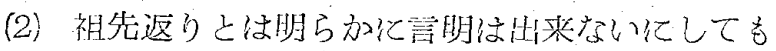
現在の哺乳類は策根の河霜であるから復古的とば 加り去元心。

\section{筜しい非対称性顔貌を星する下顎畸形の 整形手術治験例}

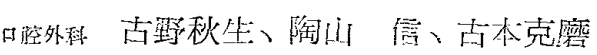

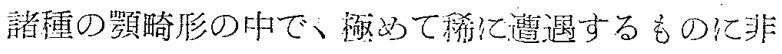

刘称性下顎畸形がある。即ち幼少持行下頍上行枝の部 分的哇失の結果、患側の発育障碍を来たし、健彔側の みは正常発育をした場合に、著しい非対称性顔貌の下 顎畸形を残すことがある。しの様な畸非に対する確実 な整死術式の記载は比較的少い。吾々は最近、此の様

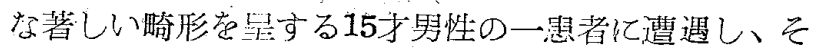
の整嫄手術を行い比较的好結果を得た。

その手街々式は

(i) 研究模型により術後㸞交安走す心゙き場所学測 七、霜列調整党行 j。

（ii）患側下頻を上行枝之骨体移行部に於て截骨し、 下顎の延長苍行う。

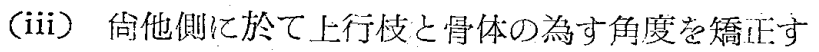
るため、Kostecka 氏洼行よる水平枝鋸断を行 j。

(iV) 次你想模型通りに咬合させ、顎間固定意行 5。

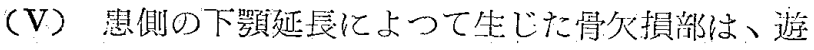
離骨移植によつて之補う。以上の方洼化より、 下顎・顔貌の非刘称性起著しく改踫することが出 来た。

\section{癌変性を伴える、エナメル上腫の一例 並びに、その処置に就て}

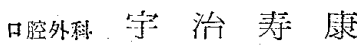

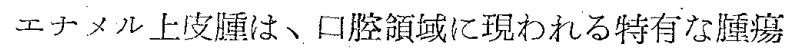

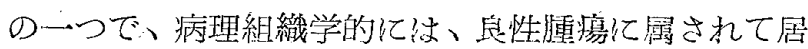
る。し加稀に、癌变性起起事は、今日达の報告例 が示す所である。私も曼近、12才の女子で、右側下顎 角部起中心として、下颚体部、及び、上行枝の大部苍

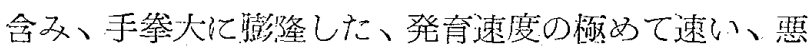
性エナメル上支腫の一例に遭遇したので坏告する。本

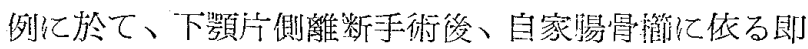
時骨移稙を行つた。

顎の耺位防止として、マルデン氏溜面釷、及び、線 副木固定袁使用したが、術後、約 7 週、レントぼン像 に於て、移植骨の先着壱確認したので、前述の囯定装

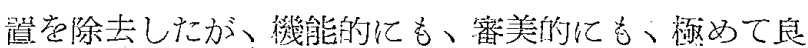
好学結果老得た。本價境の、病理組織学物には、全船

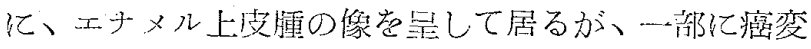
性像を珰改た。 